\title{
Looking through the bamboo curtain: an analysis of the changing role of forest and farm income in rural livelihoods in China
}

\author{
M. RUIZ PÉREZ B. BELCHER", MAOYI FU` and XIAOSHENG YANG \\ - Department of Ecology, Faculty of Sciences, Universidad Autónoma de Madrid, Spain \\ - Center for International Forestry Research, Bogor, Indonesia \\ Research Institute of Subtropical Forestry, Chinese Academy of Forestry, Fuyang, Zhejiang, P. R. China
}

Email: manuel.ruiz@uam.es

\begin{abstract}
SUMMARY
Forestry and poverty analyses in China show an ambiguous relationship. While the co-occurrence of forest rich areas and poor counties has been noted by some authors, others have stressed the role played by forestry in these areas where it is frequently one of the few options available. Our study indicates that the expansion of off-farm income is the fundamental development process taking place in many areas of rural China. Forestry can offer good income generating options to farmers, but as the local economy develops forestry tends to be displaced by more attractive alternatives. There are niche specialisation opportunities even for rich farmers, normally linked to a certain degree of vertical integration, enhanced by specific features of some forestry uses like bamboo.
\end{abstract}

Keywords: rural livelihoods, poverty, forestry, bamboo, China

\section{INTRODUCTION}

In the 25 years of post-Maoist reforms, China has demonstrated one of the most spectacular development processes of the $20^{\text {th }}$ century. Between 1978 and 2002 rural per capita income increased $528 \%$, the incidence of rural poverty declined from $30 \%$ to $3 \%$, and the economy has expanded at close to $10 \%$ annually (State Council Information Office 2001, NBSC 2003). China's growth has had a more pro-poor effect than that of the other Asian giant, India (World Bank 2002). However, this pro-poor effect has been offset to some degree by increasing income disparities (Choi 1996, World Bank 2000), and this has negatively affected the anti-poverty campaigns in China. In fact, the number of officially poor people increased by 800000 in 2003, reversing a trend of continuous decline since 1978 (Xinhua 2004).

Within this context, we examine the role of forests and forestry in poverty alleviation and rural development. How has forestry contributed to livelihood improvement? What is the role of forest-based activities and opportunities in farmers' choices? Questions of this kind have been addressed, to a certain extent in other sectors (especially in agriculture and industry) and at the macro level, but the social impacts of the policy reforms as experienced in the forestry sector are relatively poorly documented.

As in most developing countries, rural populations in China have disproportionately high levels of in- come poverty. Average rural per capita income is $32 \%$ of urban income, and rural living expenditure is less than $35 \%$ of urban living expenditure (NBSC 2003). The nature of poverty is different in rural and urban settings as well. In the Chinese context, communal lands have been allocated to households in a relatively egalitarian way within each village. Poverty in rural areas has less to do with food security than with a generally lower level of social services (health, education) and higher vulnerability when compared with urban areas (Jalan and Ravallion 1999, Liu, Hsiao and Eggleston 1999). Indeed, while rural poverty is contained and decreasing, urban poverty is now expanding quickly (CPDCR 2004).

The massive deforestation that has occurred in China has no doubt resulted in severe negative impacts on people who rely on these resources. There is a correlation between high dependence on forests and poverty, and the depletion of forest resources that has been criticized by many authors (Niu and Harris 1996, Smil 1997, Harkness 1998) can aggravate poverty. This is compounded by the poor performance of most forest industries when compared with the overall industrial sector in the country (Research Group of Forestry Economics 1998). Consequently, forest workers have among the lowest standard of living in China (Binghao and Lu 1999). Forest salaries appearing at the bottom of the list of over 60 categories or sectors published in the national statistics, and with a widening gap between national average wage 
and forest wage in recent years ${ }^{1}$. An analysis of the structure of rural farm-based income indicates that of the four sectors (crops, livestock, fish and forestry) included in Chinese statistics, forestry has experienced the lowest growth between 1985 and 2002 (NBSC several years). These facts help explain the view of Kejian and Yang (1996) that past forest interventions in the country have been a ,vicious circle of poverty - afforestation - poverty'.

At the same time, a major effort has been made to expand forest cover in these regions. Most World Bank funded forest projects have focused on poor areas, and Rozelle et al. (2000) conclude that they have been good for poverty alleviation. Some authors (see Hyde et al. 2003, Liu 2003, Liu and Yin 2004) accept that forests have a role to play in poverty reduction, but this role may have been constrained by government market controls, insecurity of tenure and other types of interventions. Forestry related opportunities will change depending on local conditions. It is quite likely that in remote areas and among minority populations, the safety net and subsistence values of forests are the most important. It is also among these populations where cash income from trade in non-timber forest products (NTFP) is relatively more important. Forestry often represents the main, or even the only, cash-income generating opportunity for many in these poor regions. Although at a national level forestry contributes only $2.3 \%$ to farm-derived rural cash income and $1.1 \%$ to total rural income (NBSC 2003), it is an important source of income in income-poor but forest-rich counties, where up to $70 \%-80 \%$ of the revenue can come from forests and forest-related activities (Da 1999, Zhang 2000). A significant part of public investment for rural environment and natural resources protection go to afforestation projects, contributing to employment creation (Rozelle et al. 2000). This investment has increased in recent years, particularly in connection to ecological programmes and a growing interest by foreign investors in plantations (Zhang 2003). Indeed, forest-based enterprises often constitute the only industry present in poor counties, serving both as main pillars for the development of the local economy and important taxpayers (Peng 1999, Zhang and Yuan 1999).

Remoteness and isolation, together with natural handicaps, have much to do with poverty, as epitomized by the mountainous and dry regions of China. Of 592 officially listed poor counties in the mid 90s, 496 were in mountainous areas (MoF 1995). And it is frequently in these regions, less accessible and with natural constraints limiting intensive agriculture, that forests have been preserved. It is therefore common to find a pattern of isolation, poverty and relatively large

\footnotetext{
${ }^{1}$ Forestry wages represented $55 \%$ of national wages in 1998 , but only $44 \%$ in 2003 (NBSC, several years).
}

forest cover, and it is difficult to disentangle the causal links.

Li and Veeck (1999), in their study of forest resource use and rural poverty in China, explore the contribution of forests to rural income in poor areas. They found a significant overlap between counties officially classified as having abundant forest resources and severe poverty counties. Using multi-county models based on county and provincial level statistics they found no relationship between forest variables and income, concluding that the availability of forestry opportunities and forest resources contribute only very slightly to per capita income. Thus, according to these authors, forestry activities in rural China are not making the direct contributions to people's livelihood that the sector could and should be making, even in forest-rich counties. Although informative and thought provoking, the work of Li and Veeck does not help us to understand the contradictory evidence and perspectives on forestry and rural poverty.

The question arises: do forest resources and forestry activities promote rural development in China or are they part of the poverty trap? We explore this question based on an analysis of the bamboo sub-sector and of the broader set of farmers' livelihoods options in a multi-county comparison.

\section{FARMERS OPTIONS IN THE CONTEXT OF CHINA'S FORESTRY}

Forestry in China is closely linked to agriculture, with forests and plantations commonly playing a complementary or supportive role in both management and income-earning (Westoby 1987, Tapp 1996). This is reflected in the unusually broad definition of forestry applied in China; ,forest' refers to most forms of tree or bush cover, including tea, and many fruit and nut species that would be classified as part of the agricultural statistics in most countries. These are designated as ,forest fruits' or ,economic forests'. It is common to have several ministries or agencies involved in the management of these economic forests, sometimes resulting in poor coordination among them, as epitomized by the case of the tea ${ }^{2}$ (Etherington and Forster 1996). At the same time, the production value of a number of these orchards and tree-based food production systems is commonly accounted as agricultural production, thus creating an imbalance between official land-use statistics and their corresponding production value. This leads to an underestimate of the value of forestry and of growth in the forest sector (Li 1996).

This fact has more than an anecdotal importance. It affects forest investment and development plans and farmers' options for forest management, and has

\footnotetext{
${ }^{2}$ Etherington and Forster (1996) report tea farmers in Yunnan saying with sarcasm: , One bush, three policies, and three departments in charge".
} 
a direct influence on understanding how forestry contributes to poverty alleviation. Forestry departments at different levels in the administration, as sole authorities or in conjunction with other departments, have the mandate to implement development plans in forest land. Designated forest land normally cannot be converted to other uses without the corresponding planning permission. Most wasteland conversion plans require that land to be converted into forest or grassland. Likewise, the Natural Forest Protection Program and similar programs elsewhere in China have as their main thrust the afforestation of arable land on steep slopes. At the same time, farmers are interested to maximize their profits within the constraints of the land use plan. Given the option, they prefer to plant fruit trees, economic forests or bamboo on land earmarked for re-/afforestation. These products have increasing demand and are far more profitable than timber, which requires long-term investments and is subject to greater market uncertainty and heavy taxation (Liu and Landell-Mills 2003) ${ }^{3}$. There is ample evidence from all over China to support this point. It can be seen in the conversion of slash and burn to rubber plantations in Yunnan (Cao and Zhang 1997); in fruit tree and bamboo plantations in the Integrated Mountain Development Plans (Forestry Economics Editorial Board 1998, Wang and Zhao 1999, Liu and Edmunds 2003); in the Southern Collective Forest Region (Liu and Landell-Mills 2003); in the authors' fieldwork experience in several counties; and even in poverty alleviation programs through forestry activities in the Loess Plateau, replacing many of the former shelterbelt program activities (Joint Survey Group 1999).

Economic forests also constitute one of the main land-uses being established in auctioned wastelands (Hanstad and Li 1997, Yu et al. 1999). Interestingly, fruit and nut trees are also often the main plantation type under the Natural Forests Protection Programme (NFPP), predominating over timber and ecological plantation forests (Zhang 2000 unpublished). This has given rise to criticism that the intended environmental benefits of the NFPP have been undermined (Zhu 2000).

Conventional (i. e., timber oriented) forests still represent the largest amount of forest land in China. They are the dominant focus of forest institutions at different administrative levels, and many farmers are engaged in their management and in the expansion of plantations, even if they are also planting economic forests (Tapp 1996, Zhang 1996). A common pattern is to have fruit trees and bamboo in more accessible areas, normally on land under individual farmer household responsibility system, contract management

\footnotetext{
${ }^{3}$ Zhao (2000) suggests that pursuing non-timber forest products (fruit trees and bamboo) may also have to do with tenure security as farmers who planted timber trees cannot cut them now under the NFPP in Simao Prefecture, Yunnan.
}

or acquired through wasteland auction schemes. Timber plantations remain in the more remote places, and are managed as individual plots, joint stock cooperatives or through joint agreements between farmers and forest farms (Kejian and Yang 1996, Zhang 1996).

The key point is that, under present circumstances and given the option, farmers, forest farms and forestry authorities ${ }^{4}$ are actively engaged in the expansion of fruit and nut trees and bamboo plantations, which are considered more profitable than conventional timber plantations and tend to have a more transparent, less burdensome taxation system, but are still classified as forestry activities.

The best indication of this trend is the increase in the area and the output of economic forests, from 6.1 million ha and 7 million metric tons $(\mathrm{mt})$ output in 1978 to 27.3 million ha and 68.8 million $\mathrm{mt}$ in 2000 , ranking China as first in the world in area and output for such crops. This change has been reflected in changes in the structure of rural markets; it has promoted rural development and relieved poverty (Lei 1999). Likewise, bamboo plantations have increased from 3.2 million ha in 1978 to 4.6 million ha in 2002 (SFA several years). Thus, while conventional (i. e. timber) forests have been depleted and timber-based forest industry is increasingly relying on imports (Sun, Katsigris and White 2004), at least until massive new timber plantations start producing, economic forests and bamboo plantations and their associated industries are thriving, offering farmers good opportunities to increase their income and to rise out of poverty.

Despite the strong growth and importance of this component of the Chinese forestry sector, analyses of forestry and poverty alleviation have typically been done from the perspective of conventional (timber) forestry. This helps explain the contradictory results of Li and Veeck, who do not differentiate between types of forests in their work, as well as some of the ambiguities in the analysis of causal relations between forestry and poverty.

\section{THE BAMBOO SUB-SECTOR}

Bamboo is an important component of Chinese forestry, having both symbolic and material value $\mathrm{e}^{5}$. There are 39 genera and close to 500 species (depending on taxonomic criteria) of which over 100 are utilised (Zhu et al. 1994). With 4.6 million ha of pure bamboo forests and plantations, and 3 million ha of ,mixed and mountain natural bamboo stands' (SFA 2003), China

\footnotetext{
${ }^{4}$ In fact, many forestry bureaus we have visited, beyond promoting fruit and nut tree crops, are also engaged in off-forest activities, like hotels, restaurants and other non-forestry related industries, showing a surprising level of diversification of economic activities.

${ }^{5}$ The words attributed to Confucius, Man can live without meat, but cannot live without bamboo' epitomize this dual value.
} 
has the largest bamboo resource base in the world. Significant amounts of woody bamboo ${ }^{6}$ occur in 17 provinces, with 10 provinces having over 100000 ha each. Four contiguous provinces (Fujian, Jiangxi, Zhejiang and Hunan) have more than half a million ha each, accounting together for over $60 \%$ of total bamboo plantations in China.

The bamboo resource base has increased steadily over the past two decades, both in surface area (32\%) and in density of stands ( $41 \%$ ). The combined expansion of plantations and increased density of stands has resulted in an exponential increase in output of bamboo culms and shoots (590\% and $1050 \%$ respectively) that contrasts sharply with the stagnant and recently decreasing output of timber.

There are important differences in the rate of expansion of different types of bamboo. Moso bamboo (Phyllostachys heterocycla var. pubescens (Mazel) Ohwi), a monopodial bamboo with high quality culms that represents over two thirds of total bamboo plantations, has expanded slower (17\%) than sympodial bamboos like Bambusa spp., Dendrocalamus spp., Sinocalamus spp. (with an $83 \%$ increase) in the last two decades.

Consequently, the fastest active expansion ${ }^{7}$ of bamboo has taken place in provinces like Sichuan where sympodial bamboos can grow. A notable exception has been Yunnan province where bamboo area has decreased $30 \%$ during this period. This decrease, which parallels the general decrease of forest resources in the province (Guo et al. 2002), has been recently redressed with the above mentioned new policies. Four southwest provinces (Sichuan, Yunnan, Guang$x i$ and Guizhou, the latter starting from a very low base) account for $73 \%$ of total new plantations established in recent years (SFA, several years). Five main features help to explain this exceptional dynamism:

- The dual use of bamboo for culms and shoots in short rotation cycles with productivity (both for land and labour) that compares with agricultural crops makes it an economically attractive option as a forest land-use to farmers.

- The relatively small management unit required (with $10 \mathrm{mu}$, equivalent to $0.66 \mathrm{ha}$, being a typical

\footnotetext{
${ }^{6}$ There are a large variety of thin-stemmed and herbaceous bamboo species that are economically less important.

We differentiate between ,active expansion" of bamboo, which is deliberately promoted by farmers, and ,passive expansion', which is due in part to the aggressive growth of bamboo rhizomes that can colonise neighbouring lands. The second is very common in monopodial bamboos, helping to explain the early use and current predominance of moso bamboo in Chinese plantations that also benefit from a less dramatic effect of synchronous flowering on Phyllostachys species (McClure 1993). However, as bamboo expands in tropical regions and new demands appear, other species are being incorporated, thus reducing the rate of expansion of moso bamboo.
}

bamboo area managed by a family in our samples) means that bamboo can easily be adapted to the household responsibility system. In our sample of counties, between $80 \%$ and $99 \%$ of total bamboo area is managed by households.

- Both bamboo culms and shoots are traded in open markets, being one of the first forest products in China to be exempted from State marketing board control. Market intermediaries, agreements between farmers and large bamboo processing firms and even incipient futures markets can be found in different regions.

- The variable scale and diversity of processing units and the possibility of a degree of pre-processing by farmers makes local processing a viable option. Bamboo epitomizes the rural value-adding industrialization approach which has been promoted in many parts of China, while its diversity of uses allows for a certain degree of county-level spatial specialisation.

- An expanding national, regional and international demand for bamboo as a substitute for wood and for some superior goods like bamboo shoots and bamboo flooring has attracted national and foreign investment ${ }^{8}$ helping to develop new technologies.

In combination these features give an economic attractiveness and a flexibility that have made bamboo a useful resource for adapting to and taking advantage of the opportunities offered by key policy reforms related to land tenure, commercialization, industrialization and exports.

\section{SOURCES OF INCOME AND LIVELIHOOD STRATEGIES}

Cross-sectional studies of bamboo farmers' income in Anji county (Zhejiang) showed that although rich farmers obtained the highest absolute income from bamboo, it was the middle income group of farmers who gained the most in relative terms (Ruiz Pérez et al. 1999). The authors' interpretation was that in a county like Anji, with a mature bamboo sector, this resource represented a normal opportunity for middle income farmers. Poor farmers were too poor to maximize the opportunity, whereas rich farmers had superior economic options available. These findings were questioned by Kant and Chiu (2000). Based in their survey of one village in Linan county (Zhejiang), they argued that the poorest farmers had benefited most from bamboo and that the income differences (measured by Gini coefficients) had been reduced. There are important methodological differences between the two studies. Notably, Ruiz Pérez et al. used quintiles to define five equal-sized income groups,

\footnotetext{
${ }^{8}$ Foreign investment was more important in the early stages of the reform, mostly during the 1980 s.
} 
and the sample was spread randomly in 8 villages in Anji. Kant and Chiu used three income classes based on official income definitions, resulting on very unequal number of farmers per class; moreover, since they only worked in one village they could not measure inter-village differences, which was the main source of differentiation in Anji study.

We decided to replicate the study and to expand it to different development contexts and levels of importance of bamboo, and to include details of all sources of income. We maintained Anji as a benchmark expanding the work to Pingjiang county (Hunan) and to Muchuan county (Sichuan) along an East-West gradient within sub-tropical China. The three counties have similar percentage of forest cover, but differ in the type of forests, capacity of established forest industry, infrastructure development, access to markets and general level of development.

Anji is a relatively prosperous county (2001 per capita income $15860 \mathrm{RMB}$ ), well connected to large external markets and big cities like Hangzhou (the capital of Zhejiang province) and Shanghai. About $58 \%$ of the county is covered by forests, of which $57 \%$ is bamboo. Most forest areas are located at the periphery of the county, while a large central plain is occupied by agriculture. Anji is a ,mature' county from a bamboo point of view, being close to a ceiling with regards bamboo plantations. With a long production tradition and well-developed and diversified processing industry, bamboo has offered farmers good income opportunities, but the expansion of the industry has to rely increasingly on bamboo from other counties.

Pingjiang is an officially poor county (2001 per capita income $3120 \mathrm{RMB}$ ) located in Hunan province within the Centre region, $600 \mathrm{~km}$ west from the coast. Around $51 \%$ of the county is covered by forests, but only $7 \%$ of the forest is bamboo. Most bamboo areas are located in the higher elevation zone in the southeast of the county, in less accessible areas, far from the main roads. Bamboo-based industry was limited to a large bamboo fan factory and few small workshops. The collapse of the factory in the early 1990s meant stagnation for bamboo until very recently. Most bamboo culm production was sold for processing in other counties.

Muchuan county is located in Sichuan province in the southwest region. It is also a low income county that has just recently emerged from the list of poor coun-ňties (2001 per capita income 4140 RMB). Located at the border of Yunnan province, the fastest expanding bamboo province in recent years, this county showed the highest bamboo expansion rate among our study areas. About $56 \%$ of the county is covered by forests, of which $38 \%$ is bamboo. Mountains divide the county into two large watersheds in the south-east and the north-west. As in the other counties, bamboo areas tend to be concentrated in these high elevation places. Most of the bamboo area is in the southern part of the county, which has better transport infrastructure and more bamboo processing factories (mainly bamboo paper for traditional and modern uses). A concentration of new bamboo plots is observed around two of the three large industrial bamboo-paper factories in the extreme south of the county.

In each county we selected three townships with bamboo resources and three villages within each township. Twenty farmers were randomly selected from each village. We used a questionnaire to collect data on land tenure status, income from different farm and off-farm activities and general family structure. Information from farmers' recall and written records was requested to assess changes in these variables over time, a task facilitated by the record-keeping tradition of many Chinese farmers. We obtained a total of 177 valid questionnaires in Anji, 159 in Pingjiang and 158 in Muchuan. For each county three equally distributed income classes were used to characterise low, middle and high income farmers to facilitate comparison between different counties.

\section{Sources of income for different income categories}

The structure of income for the five income categories used (crops, livestock, bamboo, other forests, offfarm) appears in Figure 1. The different components of farm-based income vary between counties, but offfarm income is relatively consistent (from $37 \%$ in Muchuan to $43 \%$ in Anji). As expected from county level statistics, Anji farmers get the highest share of income from forestry, followed by Muchuan and Pingiiang.

FIGURE 1 Structure offarmers' income in 2000.

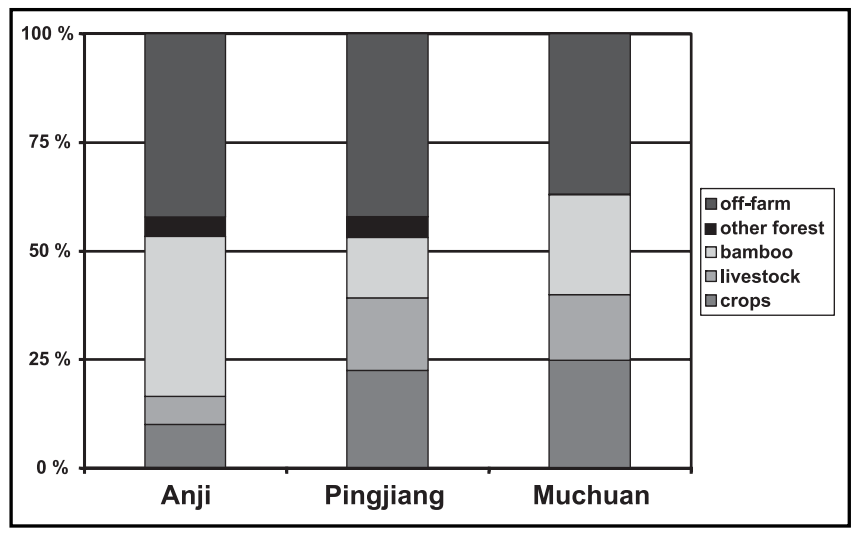

Average income for each of the three income categories (low, middle and high) was calculated for each county. Principal Components Analysis was conducted on these data, indicating the predominant sources of income by category (Figure 2).

In all three counties, high- and middle-income farmers tend to be associated with off-farm income. Low-income farmers are associated with crops and li- 
vestock, two activities that tend to play a complementary role representing the classical farm-based income in the region. These results are consistent with findings in other regions that underscore the importance of off-farm income in rural livelihoods (Lanjouw and Feder 2001, Haggblade, Hazell and Reardon 2002), an opportunity that is maximized by better-off farmers in our cases.

FIGURE 2 Principal Components Analysis biplots showing relative importance of main income sources among three income classes in 2000.

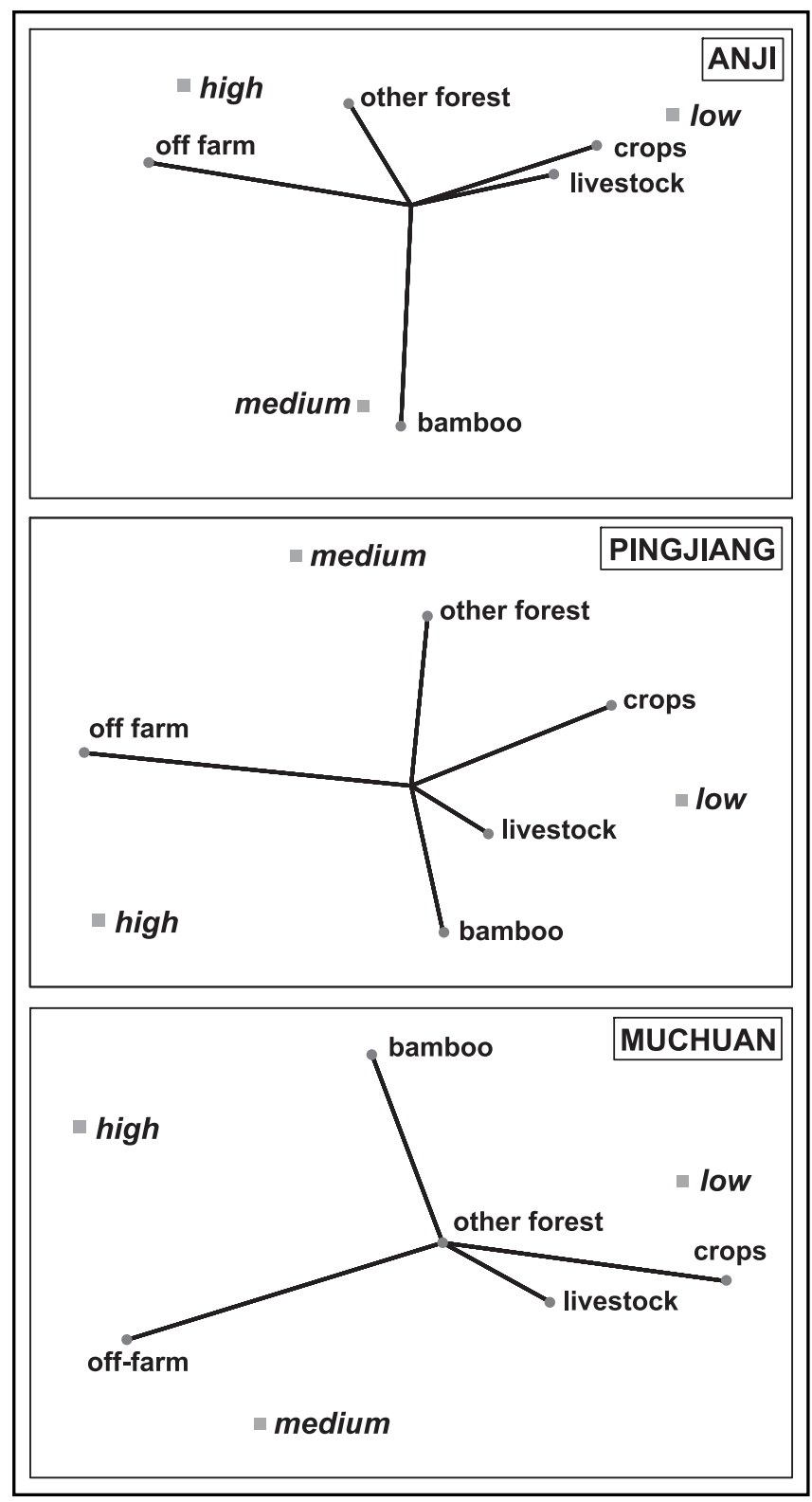

The role of bamboo changes between counties. It is associated with middle-income farmers in Anji, with high-income farmers in Muchuan, and falls between high- and low-income farmers in Pingjiang. Income from other forest activities (mainly tea and fruits, but also timber and other products) is rather small in our samples, but tends to be opposed to income from bamboo, indicating a somewhat mutually exclusive forest-related option; farmers can choose to allocate their forestry land and labour to one or another option, but seldom combine both together, signalling a certain degree of forest-based specialisation.

\section{Forest-based income distribution}

Figure 3 represents the contribution of forest-based incomes for each county and income category of farmers. Given the dominance of bamboo in forestry activities in the villages selected, a similar distribution occurs for bamboo-based income. The importance of forestry for farmers at different levels of income varies between counties. The results in Anji, based on new data from a different sample, confirm earlier findings of Ruiz Pérez et al. (1999). In this county, where bamboo- and other forest-based income opportunities have reached a plateau, with very moderate recent expansion, forestry behaves as a normal income opportunity in which middle-income farmers are involved in a more prominent way. However, in Pingjiang, where forestry has been stagnant, offering few development opportunities, low-income farmers are relatively more dependent on this source of income. The trend is reversed in Muchuan, a county where bamboo and general forestry activities have been expanding rapidly for over a decade. Here, high-income farmers make the most of the opportunity. Kruskal-Wallis tests ${ }^{9}$ show these differences are statistically significant for the last two counties (Table 1).

TABLE 1 Kruskal-Wallis test for relative contribution of bamboo and forestry to farmers' income in 2000 by low, middle and high income categories.

\begin{tabular}{lrrrr}
\hline \multirow{2}{*}{ County } & \multicolumn{2}{c}{ Bamboo } & \multicolumn{2}{c}{ Forestry } \\
\cline { 2 - 5 } & \multicolumn{1}{c}{ K-W } & sign. & \multicolumn{1}{c}{ K-W } & sign. \\
\hline Anji & 1.656 & 0.437 & 1.177 & 0.555 \\
Pingjiang & 10.226 & 0.006 & 5.046 & 0.080 \\
Muchuan & 10.898 & 0.004 & 10.869 & 0.004 \\
\hline
\end{tabular}

The results support the proposition that bamboo, and forestry activities in general, play a differentiated role in farmers' livelihood strategies according to the development context and opportunities offered by these activities. Under fast-expanding forestry conditions and with limited alternative economic opportunities, the richest farmers will benefit proportionally more from forestry resources. With stagnant forestry conditions, rich farmers will look elsewhere for the few opportunities available, and it is the poor farmers who will benefit proportionally more from forest resources. With a healthy and mature forestry sector and a wide range of opportunities, middle-income farmers are the ones who benefit proportionally most from forestry resources, falling between those who

\footnotetext{
${ }^{9}$ We have used this non-parametric test because some of the data do not follow a normal distribution.
} 
,need not' (rich farmers with access to better options) and those who ,cannot' (poor farmers, too poor to maximize the opportunity). Figure 4 represents an idealised model of this proposition.

FIGURE 3 Boxplot showing the contribution of forest income for each category of income in 2000.

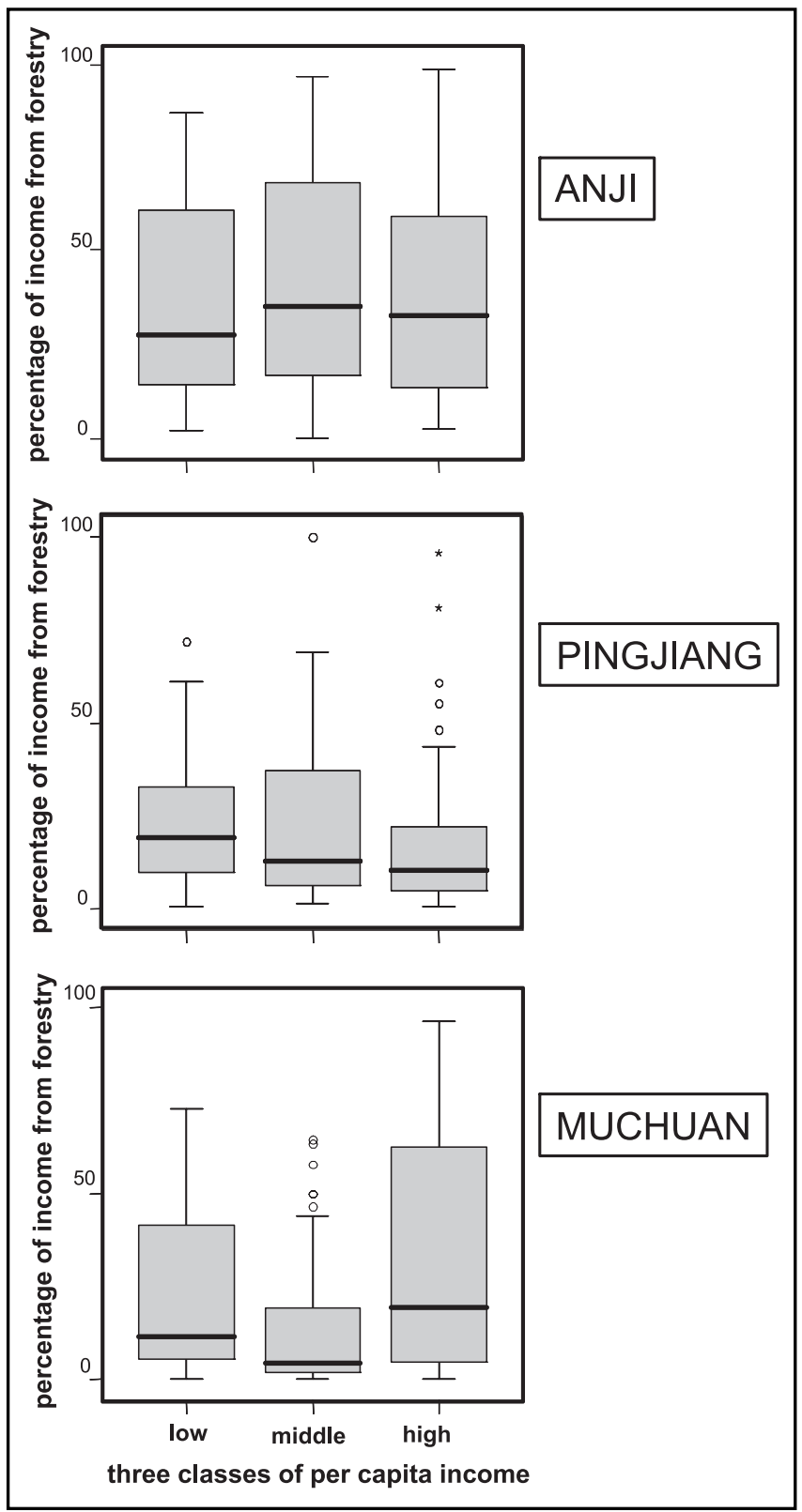

Changes in income

Income data for each of the main categories were registered for the years 1985, 1990, 1995 and 2000. A comparison of income sources in 1985 - at the beginning of the reform period - and in 2000, the year of reference for our study, is shown in Table 2 . The relative contribution of crops remained fairly stable within counties, providing the base of farming income. Livestock and forestry based incomes tended to decrease in relative importance. Off-farm income showed a dramatic increase of between 2.0 (Anji) and 2.8 times (Mu- chuan), making up an average of $40 \%$ for the three counties in 2000. These results parallel general changes in the structure of rural income in China, as reported by yearly statistics. Primary, farm-based income for

FIGURE 4 Idealised model of contribution offorest sector to farmers' income for different forest development contexts.

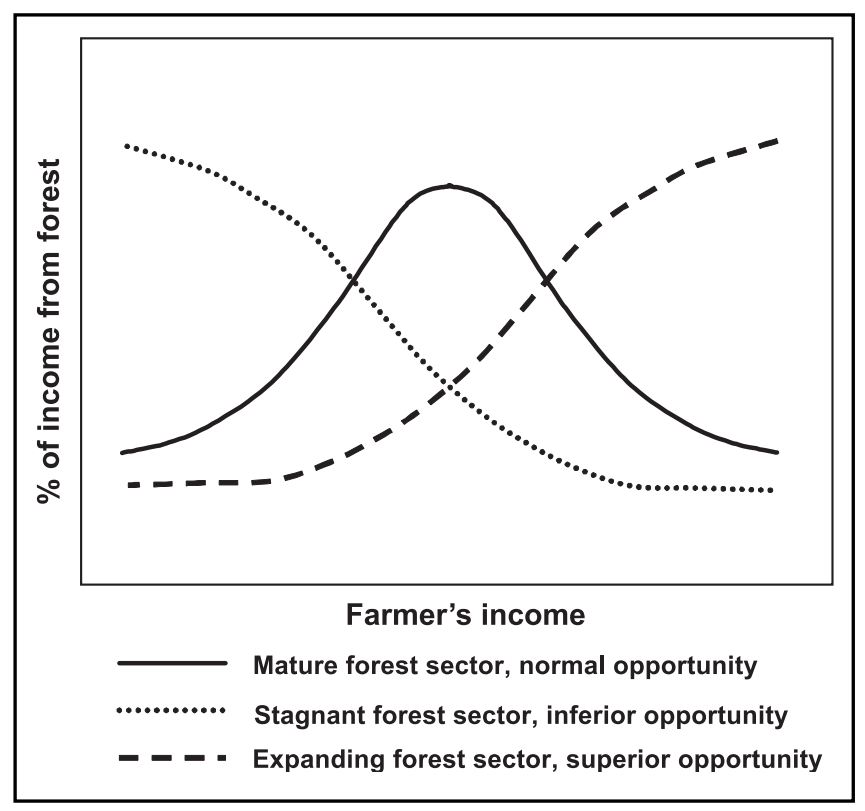

the whole country represented $81.1 \%$ of rural net income in 1985, but only $50.2 \%$ in 2002 (NBSC, several years). The reverse trend is observed for off-farm income that currently represents half the total net income in rural areas.

In order to assess rates of change, we grouped farmers in each county in three equal-sized categories of relative income change between 1985 and 2000. We used ternary plots (Figure 5) to represent changes in the main sources of income - agriculture (including crops and livestock), forestry (bamboo and other sources) and off-farm - for the three categories of income change (farmers that experienced low, middle and high income change respectively). The direction of the arrows indicates a pattern consistent with the above-mentioned findings. The relative contribution of off-farm income increases in all categories and the increase is consistently higher the higher the category of change in income, with the differences being statistically significant in the three counties (Table 3 ). Agriculture (crops and livestock) income decreased, more markedly in Muchuan and Pingjiang and less in Anji. The decrease was again consistently higher the higher the change in income category, being statistically significant for the three counties. Forestry-based income showed a more varied response, with a general decreasing trend, although the differences were not statistically significant. In Anji, with its mature bamboo sector, the higher the increase in income, the higher was the reduction in forestry income. In Pingjiang, with a stagnant bamboo sector, low and 
high income change farmers showed a higher decrease in forestry-based income. In Muchuan, a county with a strong expansion of bamboo, the higher the increase in income the lower was the decrease in income from forestry (in fact, farmers that experienced the highest change in income maintained a similar relative contribution of forestry to total income). Muchuan is also the county with the lowest average decrease in forest-based income. The differences are statistically significant in Anji (Table 3).

TABLE 2 Change in the average structure of income for each county between 1985 and 2000.

\begin{tabular}{lrrrrrr}
\hline & \multicolumn{2}{c}{ Anji } & \multicolumn{2}{c}{ Pingjiang } & \multicolumn{2}{c}{ Muchuan } \\
\cline { 2 - 7 } & $\mathbf{1 9 8 5}$ & $\mathbf{2 0 0 0}$ & $\mathbf{1 9 8 5}$ & $\mathbf{2 0 0 0}$ & $\mathbf{1 9 8 5}$ & $\mathbf{2 0 0 0}$ \\
\hline Crops & $9.7 \%$ & $\mathbf{1 0 . 2} \%$ & $\mathbf{2 7 . 2} \%$ & $\mathbf{2 2 . 8} \%$ & $\mathbf{1 9 . 9} \%$ & $\mathbf{2 4 . 9} \%$ \\
Livestock & $14.9 \%$ & $6.7 \%$ & $\mathbf{2 8 . 0} \%$ & $\mathbf{1 6 . 8} \%$ & $\mathbf{3 8 . 7} \%$ & $\mathbf{1 5 . 0} \%$ \\
Bamboo & $49.3 \%$ & $37.4 \%$ & $16.7 \%$ & $\mathbf{1 4 . 1} \%$ & $27.7 \%$ & $23.1 \%$ \\
Other forest & $4.5 \%$ & $4.5 \%$ & $\mathbf{8 . 8} \%$ & $4.6 \%$ & $0.2 \%$ & $0.1 \%$ \\
Off-farm & $21.3 \%$ & $43.0 \%$ & $19.3 \%$ & $42.7 \%$ & $\mathbf{1 3 . 0} \%$ & $36.9 \%$ \\
\hline
\end{tabular}

TABLE 3 Kruskal-Wallis test for change in relative contribution of agriculture (crops and livestock), forestry and offfarm to farmers' income between 1985 and 2000 by low, middle and high change in income categories.

\begin{tabular}{lcccccc}
\hline \multirow{2}{*}{ County } & \multicolumn{2}{c}{$\begin{array}{c}\text { Change in } \\
\text { agriculture }\end{array}$} & \multicolumn{2}{c}{$\begin{array}{c}\text { Change in } \\
\text { forestry }\end{array}$} & \multicolumn{2}{c}{$\begin{array}{c}\text { Change in } \\
\text { off-farm }\end{array}$} \\
\cline { 2 - 7 } & $\mathrm{K}-\mathrm{W}$ & sign. & $\mathrm{K}-\mathrm{W}$ & sign. & $\mathrm{K}-\mathrm{W}$ & sign. \\
\hline Anji & 38.299 & 0.000 & 30.366 & 0.000 & 49.987 & 0.000 \\
Pingjiang & 22.273 & 0.000 & 2.577 & 0.276 & 28.239 & 0.000 \\
Muchuan & 36.696 & 0.000 & 1.541 & 0.463 & 32.038 & 0.000 \\
\hline
\end{tabular}

\section{Bamboo industry wages}

The extension of this analysis to bamboo industry opportunities complements the above findings. Ruiz Pérez et al. (2003) compared bamboo-industry wages in three counties with differentiated per-capita income and development levels. In a county with low per-capita income and low levels of industrial development, the average bamboo industry wage was close to the average provincial wage. As the county increased the per-capita income and level of industrialisation, average bamboo industry wage decreased in comparison with average provincial wage (Figure 6). The interpretation is that as the county develops and the market offers better job opportunities, bamboo industries have to compete, being outperformed by more modern and dynamic industries. This view is reinforced by data on the employment of women in bamboo industries in those counties that show the reverse trend (i. e., lower percentage of women employed in bamboo industries in counties with relatively higher bamboo industry wages compared with average provincial wages), consistent with gender studies in China indicating that women are overrepresented in less attractive sectors (Riley 1995, Hare 1999, Dong et al. 2004).
FIGURE 5 Ternary plots of relative change in main income source (agriculture, forestry and off-farm) for three classes of income change (low, medium and high) between 1985 and 2000

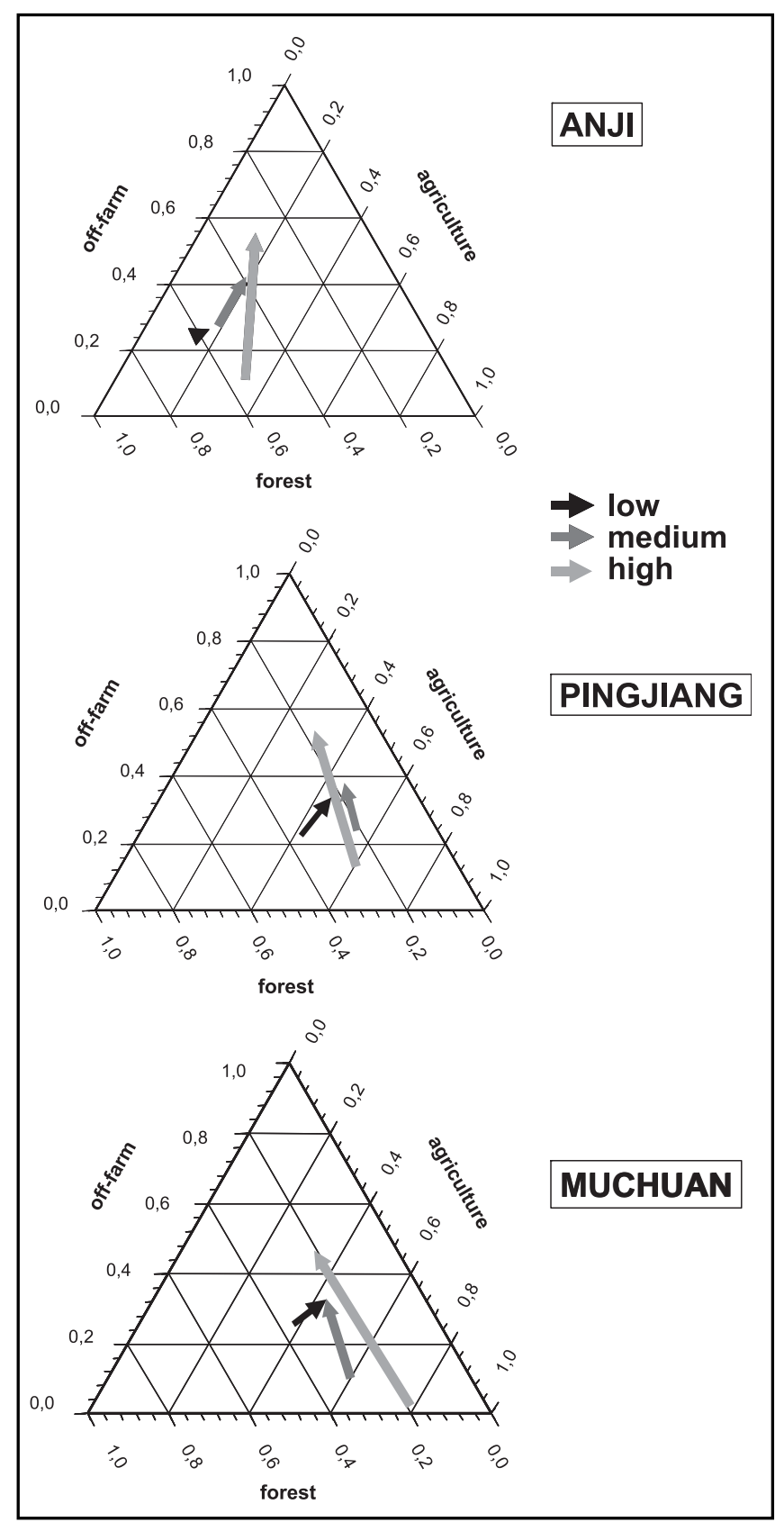

\section{Farmers' niche differentiation and specialisation through forestry}

Before concluding, we would like to stress the stochastic nature of our results that ought to be interpreted as general and probabilistic trends rather than deterministic relations. In this sense, an important question is whether forestry provides opportunities for some farmers to improve their conditions. Our data indicate that off-farm income is the main pathway up the income ladder, and that forestry and agriculture have been losing ground (faster in higher in- 
come farmers and in those whose income increased most in the period from 1985 to 2000). However, our data also show that there is a small group of farmers in the high income category in the three counties that get a substantial, even dominant, part of their income through forestry.

FIGURE 6 Relationship between per-capita income and relative ratio of bamboo industry wage to average provincial wage (modified from Ruiz Pérez et al. 2003).

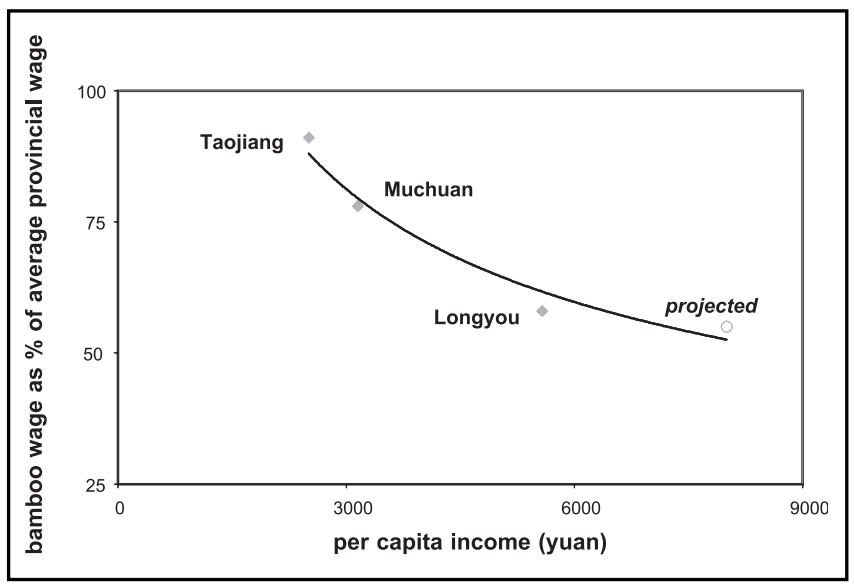

A general feature of this small group of better-off farmers with high forest-based income is a sort of ,vertical integration' at the household level, where the farmer has managed to control a large amount of forest land and at the same time has some forestry-related (trade or processing) businesses. Thus, the three largest forest land holders in Anji and Muchuan and the second and third largest in Pingjiang are in the high income class. Interestingly, this situation does not apply to agricultural land, where differences between farmers tend to be less pronounced. Indeed, the coefficient of variation (standard deviation/mean) for agricultural land is noticeably smaller than the coefficient of variation for forest land for the three counties and in all income categories (Table 4), indicating a more egalitarian division of agricultural land compared to forest land.

TABLE 4 Coefficient of variation (standard deviation) mean) for agricultural and forest land in the three counties.

\begin{tabular}{lcc}
\hline County & Agricultural land & Forest land \\
\hline Anji & 0.71 & 0.95 \\
Pingjiang & 0.55 & 1.62 \\
Muchuan & 0.59 & 1.59 \\
\hline
\end{tabular}

This indicates a potential niche for specialisation and high income generation through forestry that can be realized by a small group of dynamic farmers. This seems to be exacerbated by the conditions under which land was distributed in China and the opportunities for extended access to forest land and waste- land to be converted to forestry. This raises the intriguing question of the role of forestry in farmers' wealth accumulation and the creation of a rich class that controls land with a strong forest link in the specific context of China.

\section{CONCLUSIONS}

What is the role of forestry in livelihood change in China? An important conclusion of our work is that this link has to be understood in the general context of overall rural development processes. Off-farm income opportunities are dominant: the better the offfarm options available, the more farmers go off farm for employment, and especially those in the higher income groups. However, the symmetric statement linking reduction of farm-based activities and development does not necessarily follow, even if the expansion of off-farm implies reduction of farm-based activities.

A way to formulate this is to ask whether less forestry would lead to more development? The answer to this question will depend on the context and level of development, or the starting point from which we depart. When few alternatives are available, an expanding forestry sector is an attractive way for farmers to increase their income and for a county to develop in aggregate. However, after a certain level of development is achieved, more dynamic sectors take over as the spearhead of county's modernisation and development. At the same time, a stagnant forestry sector, even in a poor county, will not be a favoured option for middle- and high-income farmers to follow.

Independent of this general trend, forestry can offer a niche specialisation where, even with a relatively stagnant forestry sector, a smaller group of farmers can derive important benefits. In our cases this seems to be associated with a certain degree of vertical integration, where rich farmers combine relatively large forest holdings with some degree of processing and/ or trading. We lack sufficient information to extrapolate this to the rest of China, although patterns of land tenure and rural industrialisation seem to support it in the most densely populated provinces. This vertical integration is easier for certain forestry uses like bamboo, whose expansion and apparent success is facilitated by inherent advantages in raw material production and processing, including a fast rate of growth, regularity of production, diversity of uses, and diverse and wide ranging scale of processing technologies. Bamboo also has the added advantage that it is a useful wood substitute in a country with insufficient wood production capacity and policy and market constraints still affecting wood production. That is why bamboo has a bright future in Chinese forestry.

A final consideration from our research is that forestry may not only offer a pathway (under certain conditions) for farmers to emerge from poverty. In 
the Chinese context, with highly egalitarian agricultural land distribution, forestry may also be an avenue for land and wealth accumulation.

\section{ACKNOWLEDGEMENT}

We thank the Forest Bureaus of Anji, Pingjiang and Muchuan for their technical and logistic support. We also thank the European Union, the Science and Technology Office of Zhejiang and the Spanish Cooperation Agency AECI for funding of this research.

\section{REFERENCES}

BINGHAO, C. and LU, J. 1999. China's major forest regions: Natural forest protection and sustainable development. Forestry Economics [China] 5(2):816.

CAO, G. and ZHANG, L. 1997. Preliminary study on rubber plantation as the local alternative to shifting cultivation in Yunnan Province, China. Unpublished report.

CPDCR (China Population and Development Country Report). 2004. Cited by Xinhuanet, 7 September 2004. Rural poverty down, urban poverty up.

CHOI, H. 1996. Inequality of income growth in China. Asian Economics 25(4):80-91.

DA, F. 1999. Natural forest protection in Sichuan Province. Forestry Economics [China] 5(2):37-43.

DONG, X. Y., MacPHAIL, F., BOWLES, P. and HO, S. P. S. 2004. Gender segmentation at work in China's privatized rural industry: Some evidence from Shandong and Jiangsu. World Development 32(6):979998.

ETHERINGTON, D. and FORSTER, K. 1996. ,All the tea in China': The reformation and transformation of the tea industry. In: GARNAUT, R., SHUTIAN, G., and GUONAN, M. (eds). The third revolution in the Chinese countryside. pp 265-276. Cambridge University Press, Cambridge, UK.

FORESTRY ECONOMY EDITORIAL BOARD. 1998. New Actions in National Comprehensive Mountainous Development. A collection of experiences of experimental practices in various counties. Forestry Economics [China] 3(1):67-74.

GUO, H., PADOCH, C., COFFEY, K., CHEN, A. and FU, Y. 2002. Economic development, land use and biodiversity change in the tropical mountains of Xishuangbanna, Yunnan, Southwest China. Environmental Science and Policy 5:471-479.

HAGGBLADE, S., HAZELL, P., and REARDON, T. 2002. Strategies for stimulating poverty-alleviating growth in the rural nonfarm economy in developing countries. EPTD Discuassion Paper \#92. World Bank, Washington, D. C.

HANSTAD, T. and LI, P. 1997. Land reform in the People's Republic of China: Auctioning rights to wasteland. Loyola of Los Angeles International \& Comparative Law Journal 19:545-583.
HARE, D. 1999. Women's economic status in rural China: Household contributions to male-female disparities in the wage-labor market. World Development 27(6):1011-1029.

HARKNESS, J. 1998. Recent trends in forestry and conservation of biodiversity in China. The China Quarterly 156:911-934.

HYDE, W. F., BELCHER, B., and XU, J. 2003. Introduction. In: HYDE, W.F., BELCHER, B., and XU, J. (eds). China's forests. Global lessons from market reforms. pp.1-21. Resources for the Future Press, Washington, D. C.

JALAN, J. and RAVALLION, M. 1999. Are the poor less well insured ? Evidence on vulnerability to income risk in rural China. Journal of Development Economics 58:61-81.

JOINT SURVEY GROUP. 1999. Sustainable Forestry Development and Achievements in Loess Plateau. Forestry Economics [China] 4(1):10-20.

KEJIAN, O. and YANG, S. 1996. Survey of the jointstock management reform of Chunlei forest farm, Jinping county of Guizhou Province. Forestry Economics [China] 1(1):55-59.

KANT, S. and CHIU, M. (2000). Bamboo sector reforms and the local economy of Linan County, Zhejiang Province, People's Republic of China. Forest Policy and Economics 1(3/4):238-299.

LANJOUW, P. and FEDER, G. 2001. Rural non-farm activities and rural development: From experience towards strategy. Rural Development Strategy Background Paper \#4. World Bank, Washington, D. C.

LEI, J. 1999. Reform and development of forestry in China guided by the Deng Xiaoping theory. Forestry Economics [China] 5(2):17-26.

LI, Z. and VEECK, G.. 1999. Forest resource use and rural poverty in China. Forestry Economics [China] 4(1), 80-92.

LI, Z. 1996. China Forestry: The way out. Forestry Economics [China] 1(1):23-31.

LIU, C. and YIN, R. S. 2004. Poverty dynamics revealed in production performance and forestry in improving livelihoods: the case of West Anhui, China. Forest Policy and Economics 6(3/4):391-401.

LIU, D. (ed.) 2003. Rehabilitation of degraded forests to improve livelihoods of poor farmers in south China. Center for International Forestry Research. Bogor, Indonesia.

LIU, D. and EDMUNDS, D. 2003. Devolution as a means of expanding local forest management in South China: Lessons from the past 20 years. In: HYDE, W. F., BELCHER, B., and XU, J. (eds). China's forests. Global lessons from market reforms. pp.27-44. Resources for the Future Press, Washington, D. C.

LIU, J. and LANDELL-MILLS, N. 2003. Taxes and fees in the Southern Collective Region. In: HYDE, W. F., BELCHER, B., and XU, J. (eds). China's forests. Global lessons from market reforms. pp.45-58. Resources for the Future Press, Washington, D. C. 
LIU, Y., HSIAO, W. C. and EGGLESTON, K. 1999. Equity in health and health care: The Chinese experience. Social Science and Medicine 49:1349-1356.

McCLURE, F. A. 1993. The Bamboos, a Fresh Perspective. Harvard University Press, Cambridge, MA.

MoF (China Ministry of Forestry). 1995. China Forestry Action Plan. Chapter VII. Comprehensive forestry development and poverty alleviation in mountainous areas, China Forestry Action Plan.

NIU, W. Y. and HARRIS, W. M. 1996. China: the forecast of its environmental situation in the $21^{\text {st }}$ century. Journal of Environmental Management 47 : 101-114.

NBSC (National Bureau of Statistics of China). 2003. China Statistical Yearbook 2003. China Statistics Press, Beijing.

PENG, Z. 1999. Adjusting the forest benefit structure to push forestry sustainable development. Forestry Economics [China] 5(2): 51-59.

RESEARCH GROUP OF FORESTRY ECONOMICS. 1998. An analysis of the development speed and economic benefit of Chinese forestry industry enterprise. Forestry Economics [China] 3(1): 10-21.

RILEY, N. E. 1995. Chinese women's lives: rhetoric and reality. Asia Pacific Issues 25:1-8.

ROZELLE, S., HUANG, J., HUSAIN, S. A., and ZAZUETA, A. 2000. From afforestation to poverty alleviation and natural forest management: An evaluation of China's forest development and World Bank assistance. World Bank, Washington, D. C.

RUIZ PEREZ, M., ZHONG, M., BELCHER, B., XIE, C., FU, M., and XIE, J. 1999. The role of bamboo plantations in rural development: the case of Anji County, Zhejiang, China. World Development 27(1): 101-104.

RUIZ PEREZ, M., BELCHER, B., FU, M., and YANG, $X$. 2003. Forestry, poverty and rural development: Perspectives from the bamboo sub-sector In: HYDE, W. F., BELCHER, B., and XU, J. (eds). China's forests. Global lessons from market reforms. pp.151-176. Resources for the Future Press, Washington, D. C.

SMIL, V. 1997. China shoulders the cost of the environmental change. Environment 39(6): 6-37.

STATE COUNCIL INFORMATION OFFICE. 2001. White Paper on Rural China's Poverty Reduction. State Council Information Office, Beijing.

SFA (State Forest Administration) (several years). Chinese Forestry Yearbook [in Chinese]. China Forestry Publishing House, Beijing.

SUN, X., KATSIGRIS, E, and WHITE, A. 2004. Meeting China's growing demand: An overview of import trends, ports of entry, and supplying countries, with emphasis on the Asia-Pacific Region. Forest Trends-CCAP-CIFOR.

TAPP, N. 1996. Social aspects of China fir plantations in China. Commonwealth Forestry Review 75(4): 302-308.
WANG, C. and ZHAO, X. 1999. Components and measures for integrated mountain development in China. Forestry Economics [China] 4(1): 21-29.

WESTOBY, J. 1987. Making green the Motherland: Forestry in China. In WESTOBY, J. (ed). The purpose of forests. Follies of development. pp. 270-287. B. Blackwell, Oxford

WORLD BANK. 2000. World Development Report, 2000-2001.World Bank, Washington, D. C.

WORLD BANK. 2002. India and China: Which country has experienced more pro-poor growth and why ? PREM Learning Week, World Bank, Washington, D. C.

XINHUA. 2004. 800000 more Chinese live in poverty in 2003. Xinhua News, 20 July 2004.

YU, G., YU, L., HUANG, C. and CHEN, G. 1999. Survey and exploitation on forestland transfer in integrated mountainous development. Forestry Economics [China] 4(1): 30-34.

ZHANG, D. and YUAN, R. 1999. Problems and countermeasures for the development of rosin derivative products for naval stores industry in China. Forestry Economics [China] 4(1): 61-66.

ZHANG, D. 2003. Policy reform and investment in forestry. In: HYDE, W.F., BELCHER, B., and XU, J. (eds). China's forests. Global lessons from market reforms. pp.85-108. Resources for the Future Press, Washington, D. C.

ZHANG, L. 1996. Full scale promotion of degraded land tenure for acceleration of plantation and poverty relief. Forestry Economics [China] 1(1): 6063.

ZHANG, Z. 2000. Natural Forest Protection Program. First meeting of the China Council for International Cooperation on Environment and Development. Forests-Grasslands Task Force. Unpublished notes from presentations and discussions on July 18 and 19, 2000.

ZHAO, Y. 2000. Impacts of the logging ban on the community in Simao Prefecture, Yunnan Province. First meeting of the China Council for International Cooperation on Environment and Development. Forests-Grasslands Task Force. Unpublished notes from presentations and discussions on July 18 and $19,2000$.

ZHU, C. 2000. Case study on returning steep cultivated land to forests: Policy and its impacts. First meeting of the China Council for International Cooperation on Environment and Development. Forests-Grasslands Task Force. Unpublished notes from presentations and discussions on July 18 and 19, 2000.

ZHU, S., MA, N. and FU, M. 1994. A Compendium of Chinese Bamboo. China Forestry Publishing House, Beijing. 